\title{
A Survey on Application of English Learning APPs to English Listening and Speaking Course in English Major
}

\author{
Jinghuo Zhang, Yan Liu \\ College of Foreign Languages Education and International Business, Baoding University, Baoding, China \\ Email: liuyanhuo81@163.com
}

How to cite this paper: Zhang, J. H., \& Liu, Y. (2021). A Survey on Application of English Learning APPs to English Listening and Speaking Course in English Major. Creative Education, 12, 1307-1313. https://doi.org/10.4236/ce.2021.126098

Received: April 25, 2021

Accepted: June 14, 2021

Published: June 17, 2021

Copyright $\odot 2021$ by author(s) and Scientific Research Publishing Inc. This work is licensed under the Creative Commons Attribution International License (CC BY 4.0).

http://creativecommons.org/licenses/by/4.0/

\section{(c) (i) Open Access}

\begin{abstract}
This paper discusses the application of English learning Apps to English listening and speaking course in English majors at Baoding University. Using students' and teachers' questionnaires, the conclusion is drawn. With the help of English learning APPs, students in English majors can increase their interest and strengthen their confidences in studying English listening and speaking in class. At the same time, English teachers are willing to use English learning Apps to help students improve students' English listening and speaking abilities. The teaching model can help teachers of English listening and speaking course to adjust teaching strategies actively and it is also the orientation of the reform for English teaching at Baoding University.
\end{abstract}

\section{Keywords}

English Learning APPs, English Majors, Listening and Speaking Course

\section{Introduction}

In recent years, mobile teaching mode becomes popular in education, especially in higher schools. This mode can take on the teaching activities at any time and at any place, which will be an integral part in the future education. The mobile terminal involves computer equipment which is used in motion. All kinds of mobile phones, tablets, laptops, and other devices belong to the mobile terminal. App is an abbreviated form of the word application and means "a piece of software", which can be understood that the third-party application is on mobile smart terminals. The advantages of the mobile teaching modes can be seen very clearly: it makes the communication between teacher and students easier; it provides the variety of teaching material; it enriches additional activities after class 
(Wang, 2015). Some English learning Apps on the mobile phone can be used for arousing students' interest in English learning, especially in English listening and speaking. Before class, teacher can use gather English news or English movies related to the unit topic from English learning Apps, such as BBC, iQIYI and so on and then give the task to the students after they listen to this material. In class, teacher can use the technology of recording or imitating from APPs to test students' ability of listening and speaking. After class, additional activities and exercises can be sent to students from English learning Apps to consolidate the skills of English listening and speaking.

In recent years, with the development of Internet, scholars and professors in English education make effort to adopt the technology to accelerate the steps of the reform of English classes. They have done the research and experiment on related field and put forward valuable methods and opinions. Wang Lanlan (2015) did the research on commutative intention and found that $79.5 \%$ of college students are willing to communicate with foreigners in English on QQ or other chatting instruments. It can be shown that college students' acceptance and willingness for communication on line is higher than that in class or face-to-face. On the Chinese Knowledge Network (CNKI), "Mobile teaching platform and English" and "App and English teaching" were the subjects of the author's search for journal papers, master theses, and doctoral theses from 2016 to 2020 respectively and sixty one papers and eight hundreds and ten papers were published in public.

It can get information from table, in recent years, the number of related research literature on Apps and English teaching in China is increasing (Table 1).

Overall, although there are many pieces of research on English learning Apps in English teaching in China, it has not formed an excellent academic system. The application of English learning Apps in English listening and speaking course in English major needs to be enriched and strengthened.

The exploration of the application of information technology in second language teaching began in the middle of the 20th century. In the 1990s, the emergence of network technology brought a new period to the combination of information technology and foreign language teaching. In 1996, in a report about information technology, the French Academy of Sciences proposed the application of multimedia technology in the field of teaching. Han. H. P researched how to apply the technology such as television or film to assist second language teaching in 1994. In the study, the results of questionnaires and interviews show that this method is helpful to improve students' listening level and oral communicative competence (Han, 1994). To sum up, foreign countries have been exploring

Table 1. The number of research paper related from 2016 to 2020.

\begin{tabular}{cccccc}
\hline & 2016 & 2017 & 2018 & 2019 & 2020 \\
\hline Mobile teaching platform and English & 5 & 7 & 17 & 21 & 11 \\
App and English teaching & 69 & 141 & 186 & 226 & 188 \\
\hline
\end{tabular}


English teaching using information technology for a long time, and also carried on the practice unceasingly and obtained the certain result, provided the basis and the instruction for our future research.

\section{Methodology}

The paper tries to investigate students' attitudes towards English listening and speaking classes, students' and teachers' intention to use English Apps to exercise, the problems faced by English teachers and students who use English learning Apps in English speaking and listening course and the effectiveness of English learning Apps in improving English listening and speaking. From the survey on the above questions, it will deal with the following research questions: whether English learning Apps are useful in college students' English listening and speaking abilities; whether college students can use these Apps effectively; whether the Apps can arouse college students' learning interests in English listening and speaking (Tao, 2014). The research subjects of the paper included one hundred students in grade 2019 in English major of Baoding university and ten teachers who are teaching English listening and speaking course or have ever taught this course. All of the students have learned the English listening and speaking course for one year since they began to study at Baoding University. They have received the tradition teaching in the high middle school and are trying to use the English Apps to change their learning ways. Questionnaires for students and teachers are used to show the reliability. Two kinds of questionnaires are made based on the research objectives and research questions. The questionnaires investigate the use condition of English learning Apps by students and teachers respectively. It provides powerful evidence for accurate statistics of English listening and speaking in English listening and speaking course. All the questionnaires for students are sent out to ninety-five students in class and questionnaires for teachers are sent out respectively to ten teachers who are having English listening and speaking classes and have ever had the classes. The questionnaires and data are valid. The collected data are sorted out and analyzed and the conclusions are drawn.

\section{Results and Discussion}

This part introduces the research data of the paper. The author analyzes and discusses results of the questionnaires and interviews.

\subsection{Data Analysis and Discussion of the Questionnaires for Students}

It includes two parts of the students' questionnaires. The first part is the students' attitudes towards English listening and speaking course, and the second part is the analysis of questions in questionnaires.

This table analyzes students' learning interests about English listening and speaking classes in English major (Table 2). Through the data, it can be clearly 
Table 2. Students' interest in English listening and speaking.

\begin{tabular}{|c|c|c|c|}
\hline Investigation & Choices & Quantity & Percentage \\
\hline \multirow{4}{*}{$\begin{array}{l}\text { Are you interested in English } \\
\text { listening and speaking class? }\end{array}$} & Very much & 12 & $12.63 \%$ \\
\hline & Quite a lot & 22 & $23.16 \%$ \\
\hline & Just so-so & 38 & $40 \%$ \\
\hline & Not at all & 23 & $24.21 \%$ \\
\hline \multirow{4}{*}{$\begin{array}{l}\text { How do you involve in English } \\
\text { listening and speaking class? }\end{array}$} & Active to involve & 8 & $8.42 \%$ \\
\hline & Passive to involve & 68 & $71.58 \%$ \\
\hline & Seldom involve & 16 & $16.84 \%$ \\
\hline & Never involve & 3 & $3.16 \%$ \\
\hline \multirow{4}{*}{$\begin{array}{c}\text { How do you deal with listening } \\
\text { and speaking homework? }\end{array}$} & Deal with it seriously & 53 & $55.79 \%$ \\
\hline & Deal with it selectively & 11 & $11.58 \%$ \\
\hline & Deal with it casually & 28 & $29.47 \%$ \\
\hline & Never do & 3 & $3.16 \%$ \\
\hline \multirow{4}{*}{$\begin{array}{l}\text { How much time do you spend } \\
\text { on English listening and } \\
\text { speaking exercises every day? }\end{array}$} & More than half an hour & 15 & $15.79 \%$ \\
\hline & About 20 minutes & 30 & $31.58 \%$ \\
\hline & About 10 minutes & 33 & $34.74 \%$ \\
\hline & No & 17 & $17.89 \%$ \\
\hline
\end{tabular}

seen that only $35 \%$ of students are interested in English listening and speaking course while more than $60 \%$ of students have not the interest in the course. It is not active for students' performance in English listening and speaking class shown in the table, in which less than $9 \%$ of students can participate actively in the class, but the majority of the students take part in the activities in class passively. For the homework and after-class listening and speaking exercises, the table shows that more than half of the students can do the homework seriously but spend little time on exercise listening and speaking in English after class. It is not enough for English major students to improve their ability of English listening and speaking.

This table shows students' attitudes towards English learning Apps for improving English listening and speaking ability (Table 3). The result from the table turns out more than $70 \%$ of the students like using English learning Apps to do the homework and after-class exercises on English listening and speaking. About $10 \%$ of students don't care about whether the English learning Apps are used or not and about $6 \%$ of students don't like using such Apps. Most students think that through using English learning Apps their confidence in English listening and speaking can be improved. However, about $20 \%$ of students have different views on that.

\subsection{Questionnaire for Teachers}

Teachers' questionnaires are divided into two parts according to their mastery 
Table 3. Students' attitudes towards English learning Apps.

\begin{tabular}{cccc}
\hline \multicolumn{1}{c}{ Investigation content } & Choices & Quantity & Percentage \\
\hline & Very much & 26 & $27.37 \%$ \\
$\begin{array}{c}\text { Do you like to do homework for } \\
\begin{array}{c}\text { English listening and speaking by } \\
\text { English learning Apps? }\end{array}\end{array}$ & Quite a lot & 45 & $47.37 \%$ \\
& Just so-so & 18 & $18.95 \%$ \\
& Not at all & 6 & $6.32 \%$ \\
\hline $\begin{array}{c}\text { Do you think using English learning } \\
\text { Apps can improve your confidence } \\
\text { in speaking and listening? }\end{array}$ & Very much & 33 & $34.74 \%$ \\
& Quite a lot & 35 & $36.84 \%$ \\
& Just so-so & 20 & $21.05 \%$ \\
\hline
\end{tabular}

and effectiveness for using English learning Apps. Ten teachers from College of Foreign Languages Education and International Business of Baoding University in China participate in making the research. They are all from the English department and are teaching or have ever taught English listening and speaking course.

It can be shown from the table among ten teachers, eight teachers know well about English learning Apps and five teachers usually use English leaning Apps in English listening and speaking class. Eight teachers are willing to use English learning Apps in their daily teaching to enhance their students' English listening and speaking levels. However, $20 \%$ of teachers do not comprehend English learning Apps very well and 50\% of teachers haven't apply this technology into the English listening and speaking class because they are not interest in computer technology (Table 4). Therefore, teachers' cognition of English learning Apps should be enhanced either.

The information gathered from a questionnaire about the influence of English learning Apps. 20\% of teachers think that English learning Apps have no impact on increasing students' interest in English listening and speaking study. In addition, $50 \%$ of teachers admit that students' listening and speaking levels can be risen by using English learning Apps. And 30\% of teachers think that it has an influence on English listening and speaking teaching and learning (Table 5). Through the data, it can be easily seen that most teachers think that the use of English learning App to exercise English listening and speaking exercises is beneficial to the improvement of students' enthusiasm for students' English learning and speaking.

It can be clearly seen that using English learning Apps in English listening and speaking course is a challenge. Many teachers are realizing the shortage of English listening and speaking teaching and agree that using English learning Apps can improve students' listening and speaking ability effectively. But some teachers worry that giving students too much exposure to the APPs will distract them due to students' weak self-control ability. Most of teachers agree that English learning Apps can bring benefits to students and the current situation of English listening and speaking teaching. 
Table 4. Teachers' understanding and mastery of English learning Apps.

\begin{tabular}{|c|c|c|c|}
\hline Investigation content & Choices & Quantity & Percentage \\
\hline \multirow{4}{*}{$\begin{array}{c}\text { Do you know the English learning Apps for } \\
\text { English listening and speaking? }\end{array}$} & Very much & 3 & $30 \%$ \\
\hline & Pretty & 5 & $50 \%$ \\
\hline & Just so-so & 2 & $20 \%$ \\
\hline & No & 0 & 0 \\
\hline \multirow{4}{*}{$\begin{array}{l}\text { How often do you use English learning Apps } \\
\text { in English listening and speaking class? }\end{array}$} & Very much & 1 & $10 \%$ \\
\hline & Pretty & 4 & $40 \%$ \\
\hline & Just so-so & 3 & $30 \%$ \\
\hline & No & 2 & $20 \%$ \\
\hline \multirow{4}{*}{$\begin{array}{c}\text { Are you willing to use English learning Apps } \\
\text { of listening and speaking in class? }\end{array}$} & Very much & 4 & $40 \%$ \\
\hline & Pretty & 4 & $40 \%$ \\
\hline & Just so-so & 1 & $10 \%$ \\
\hline & No & 1 & $10 \%$ \\
\hline
\end{tabular}

Table 5. The effectiveness of the application of English learning Apps.

\begin{tabular}{cccc}
\hline Investigation content & Choices & Quantity & Percentage \\
\hline & Very much & 2 & $20 \%$ \\
$\begin{array}{c}\text { Can English learning Apps activate students' } \\
\text { interest in English listening and speaking? }\end{array}$ & Pretty & 3 & $30 \%$ \\
& Just so-so & 3 & $30 \%$ \\
No & Very much & 2 & $20 \%$ \\
\hline students' listening and speaking ability? & Just so-so & 3 & $20 \%$ \\
& Pretty & 3 & $30 \%$ \\
\hline
\end{tabular}

\section{Conclusion}

The results of the survey discover that students prefer learning and practicing English with Apps to traditional English learning only through textbooks and teachers. At the same time, the use of English learning APP to assist the English listening and speaking course model is also welcomed by English teachers. This kind of Apps provides a large number of learning resources to reduce the teachers' burden to prepare the lesson materials. It also can activate the atmosphere in class and rich oral practice methods. Therefore, this method will improve students' oral English level and listening ability.

Therefore, teachers should lead students and assist them to make up for their lack of listening and speaking learning practice. For those students who cannot master the correct pronunciation, the teachers should assign more shadowing exercises on English learning Apps to give students more time to practice in order to strengthen their impressions. For those who dare not speak English in 
class, the teachers should pick out the exercises to talk with the machines on English learning Apps to guide them with patience and encouragement. In such way, students can make greater progress in listening and speaking learning. Through the teaching process, students will perceive the significance of listening and speaking learning, so as to achieve the purpose of teaching.

\section{Funding}

The thesis is the research result of Research and Practice Project of English Teaching Reform for Ordinary Undergraduate Colleges in Hebei Province in 2019, project number: 2019YYJG057.

\section{Conflicts of Interest}

The authors declare no conflicts of interest regarding the publication of this paper.

\section{References}

Han, H. P. (1994). Implementing the Video-Based Instruction in the College-Level ESL Classroom Based on Second Language Acquisition and Communication Competence Theories. USA: North Carolina State University.

Tao, Y. (2014). A Brief Discussion on the Application of Cellphone Media in English Major's Acquisition of Listening and Speaking Abilities. The Science Education Article Collects, 6, 79-80.

Wang, L. L. (2015). An Investigation of L2 WTC by College Learners of English in the Web-Based Environment. Journal of Beijing International Studies University, 6, 67-74. 